\title{
Organizational and economic mechanism for the development of the oil and gas complex of developing countries
}

\author{
K.Y.B. Cofie \\ Postgraduate student, St. Petersburg Mining University, Saint Petersburg, Russia \\ N.V. Romasheva \\ Ph.D. of Economic Sciences, Assistant professor, Petersburg Mining University, Saint Petersburg, Russia
}

\begin{abstract}
Republic of Côte d'Ivoire is the world's largest producer and exporter of cocoa beans and a major producer and exporter of coffee and palm oil. By the fact that the country's economy is very sensitive to fluctuations in world prices for these products, in recent years there has been a diversification of the economy due to the development of other sectors of the industry, including the oil and gas complex. For a long time, the successful development of the oil and gas complex was observed, however, in 2017, the country's investment and geological attractiveness sharply declined, the contribution of the oil and gas sector in the gross domestic product decreased significantly. The article is devoted to identifying strengths and weaknesses, as well as opportunities and threats for the development of the Côte d'Ivoire oil and gas complex, analyze regulatory aspects of its functioning. As a result of the analysis and systematization, recommendations for improving instruments and methods of its regulation was made. The research was based on publications by Russian and international experts in scientific electronic and printed journals such as Energy Policy, Energy Reports, Petroleum Exploration and Development, The Extractive Industries and Society, Resources Policy, Resources, etc. The methodology of the research includes desk studies, comparative, logicalstructural, situational analysis, decomposition method and SWOT - analysis.
\end{abstract}

\section{INTRODUCTION}

Primary energy consumption grew at a rate of $2,9 \%$ last year, almost double its 10 -year average of $1,5 \%$ per year. By fuel, energy consumption growth was driven by natural gas, which contributed more than $40 \%$ of the increase. Oil consumption grew by an above average 1,4 million barrels per day, or 1,5\%. Oil remains the dominant fuel in Africa, Europe and the Americas, while natural gas dominates in the Commonwealth of Independent States (CIS) and the Middle East, accounting for more than half of the energy mix in both regions (BP: Statistical Review of World Energy - 2019 edition). In modern conditions, hydrocarbons are one of the main energy resources that can satisfy the energy needs of a growing population and a developing global economy (Smirnova\&Rudenko 2017).

In recent times, the promise of oil and gas reserves and resources in Africa (Khatib 2014; Modelevsky\& Modelevsky 2016) continues to generate a great interest in achieving national economy growth by its exploration and to attract new investment, especially from China and India (Ayanoore 2020; Graham\&Ovadia 2019). This fact led to different policy initiatives and regulatory base development in such countries as Nigeria, Angola, Tanzania, Uganda and Ghana, aimed at securing greater oil and gas rents (Ayanoore 2020; Hansen et al. 2016; Ovadia, 2016).

The economy of Republic of Côte d'Ivoire has always been based on agriculture, but the past few decades have seen economic diversification through the development of various industries, including the oil and gas complex (Côte d'Ivoire - Country Strategy Paper; Kuadio \& Dukart). Oil and gas production has been increasing for several years, but in recent years there has been 
a decline in its development: there is a decrease in the share in gross domestic product, in investment inflows, in the number of foreign companies and new projects.

It is known that policy initiatives and regulatory frameworks have a great impact on an effective industry development, including the oil and gas complex (Araujo \& Leoneti 2019; Lipina et al.2018; Mukesh 2016), so it can be suggested that regulatory framework in Republic of Côte d'Ivoire does not include measures that promote foreign investments, does not create conditions for successful functioning of oil and gas companies.

So, this paper attempts to investigate the current situation in the Côte d'Ivoire oil and gas complex, analyze and classify instruments and methods of state regulation in considered sphere, in order to make recommendations for accelerate the pace of oil and gas complex development.

\section{LITERATURE REVIEW}

Features and development trends of the developing countries' economies were investigated in the Lewis William Arthur, Rostow Walt Whitman, Samir Amin and others' works (Lewis 1955; Rostow 1971). The papers of many Russian and foreign scientists are devoted to general aspects of government regulation of a market economy, state regulation, functioning and development of the oil and gas sector (Cherepovitsyn, Moe \& Smirnova 2016; Deberdieva 2015; Gubin 2018; Mihalchenkova 2004; Oreshin 1999; Romasheva\&Ilinona 2019; Trofimov 2018).

A great number of researchers deal with regulatory framework in various context. Some papers examine the role and challenges of local content policies for petroleum and mining in different African countries (Graham\&Ovadia 2019; Ovadia 2016). Several publications are devoted to the study of oil and gas regulatory framework attractiveness to investors (Araujo \& Leonetti 2019; Florêncio 2016). In several papers, the authors tried to analyze institutional arrangements and the importance of the national oil and gas companies (Melyoki 2017; Paz \& Cendero 2013). Some authors investigated the government support tools, policy preferences, fiscal regimes, priorities for improving taxation in oil and gas industry (Cendrero \&Paz 2017; Lipina 2018; Mayer 2017; Smirnova \& Rudenko 2016), others analyze the regulatory changes and factors that resulted in the limited success of a regulatory framework (Khatib 2014; Mukesh 2016).

However, despite the large number of different publications on the research topic, several aspects of state regulation of oil and gas resources development in specific country require further research. A small number of articles are devoted to the Côte d'Ivoire oil and gas complex development and its regulation (Liu et al. 2010; Kuadio \& Dukart). So, the present study analyzes the prospects and problems of the Côte d'Ivoire oil and gas complex development, as well as policy incentives and regulatory framework.

\section{RESEARCH METHODS AND MATERIALS}

In the research, desk studies, comparative, logical-structural, situational analysis, decomposition method was carried out to generalize, analyze, and systematize information in order to understand the current situation in oil and gas complex, its importance for Côte d'Ivoire economy development and to reveal instruments and methods of state regulation in Côte d'Ivoire' oil and gas sector.

This paper uses a SWOT analysis method to identify the internal strengths (S) and weaknesses (W) and external opportunities (O) and threats (T) facing Côte d'Ivoire' oil and gas complex development. Findings from the SWOT analysis helps understand strengths, realize new opportunities as well as work towards the minimization or elimination of any possible threat to the business (Agyekum, Ansah \& Afornu).The SWOT analytical tool is widely accepted by researchers in the energy sector for energy planning.

The research was based on publications by Russian and international experts in scientific electronic and printed journals such as Energy Policy, Energy Reports, Petroleum Exploration and Development, The Extractive Industries and Society, Resources Policy, Resources, etc. 
The legal basis of the study is formed by analyzing the regulations of the Republic of Côte d'Ivoire, economic and financial reviews and statistical materials the Republic of Côte d'Ivoire government.

\section{RESULTS}

The study of oil and gas potential began in 1941, when the African Oil Company (SAP) announced that the subsoil of Republic of Côte d'Ivoire was not promising for the presence of hydrocarbon resources. However, exploration had been conducted since 1970, covering an area of 22,740 sq. km. in the coastal sedimentary basin of Côte d'Ivoire Republic, led to the discovery of the first oil field in 1974. The development of this area was carried out by the operator ESSO from 1980 to 1992 using a fixed platform. The continuation of prospecting has revealed signs of the presence of oil and natural gas in other areas of the coast. The Government of Côte d'Ivoire has entered contracts for prospecting with a few the world's largest oil monopolies. Since then, more than 207 wells have been drilled in the coastal sedimentary basin of Côte d'Ivoire Republic of, leading to the discovery of eight fields, four of which are currently in use. Most of the deposits now discovered are in the Abidjan region.

Analyzing the dynamics of oil and gas production, it can be concluded that their production has been unstable over the past 5 years (Figure 1). Real gross domestic product (GDP) growth was $7.4 \%$ in 2018 (Figure 2) and could remain above 7,0\% during 2020-2021. Figure 2 shows the share of the oil and gas industry in gross domestic product (GDP), which in 2018 amounted to $0.83 \%$ and significantly decreased compared to 2015 . Compared to income from agricultural production, oil and gas revenues look negligible.

This decrease occurred as a result of changes in oil and gas prices, the strengthening of other industrial sectors, and the absence of a well-developed investment policy.

According to the general index of attractiveness for investment, as shown by a Fraser Institute study, in 2017 Republic of Côte d'Ivoire fell from 17th to 78th place in the world; in terms of the policy perception index, it occupies 67 th place $(2016-40$ th place); in terms of geological attractiveness - 73rd place (2016 - 9th place). The significant decline happened due to an insufficiently effective and transparent legal and tax system, low quality infrastructure, trade barriers, relative political instability, security threats, poor quality of available geological information, and a lack of qualified personnel.

Among the advantages can be identified exploration potential, however, the development of deposits requires unique technologies - the depth of the sea reaches $3500 \mathrm{~m}$, clear regulation of environmental protection and protected areas.

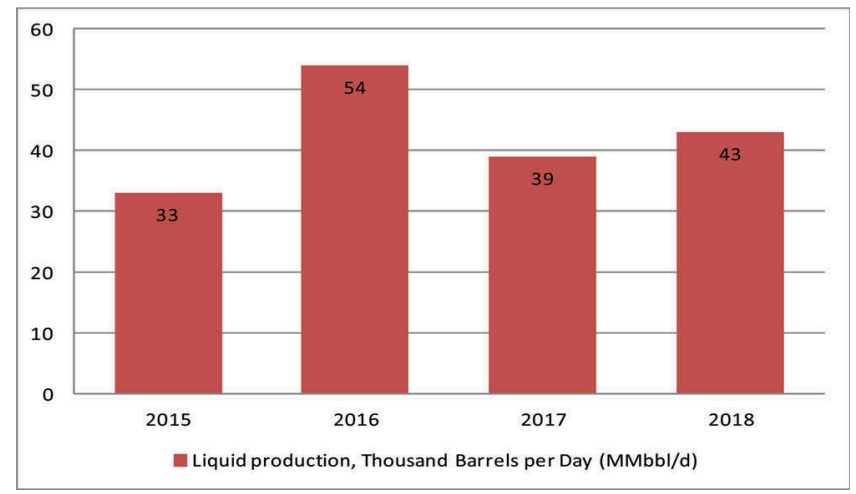

Figure 1. Cote d'Ivoire liquid production from 2015 to 2018. 


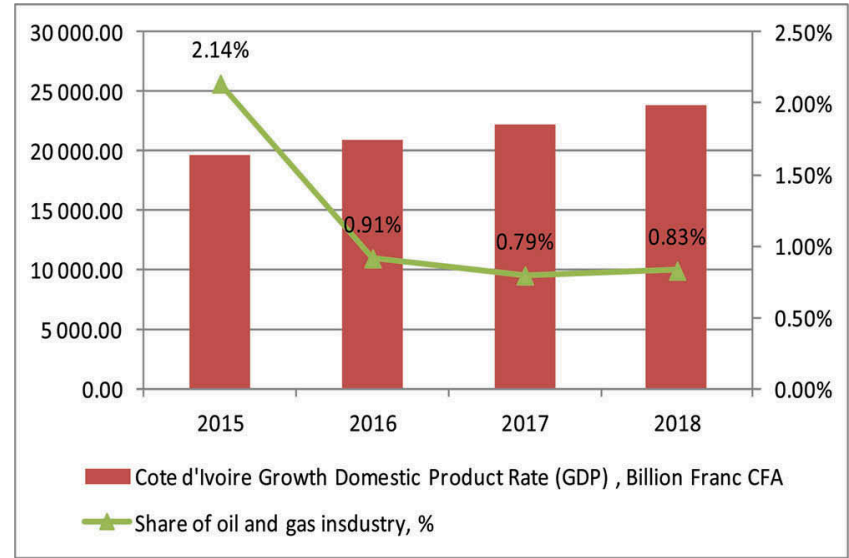

Figure 2. Cote d'Ivoire GDP Rate and contribution of Oil and gas sector to the local economy.

Nevertheless, according to the Ministry of Energy, it is planned to increase oil production over 5 years to 200 thousand barrels per day, which will be possible thanks to recently discovered large oil and gas fields, as well as ongoing exploration drilling.

In the paper, strengths-weaknesses-opportunities and threats analysis (SWOT) as a methodology for analyzing the Côte d'Ivoire Republic oil and gas complex from an internal and external perspective was made (Table 1).

Table 1. SWOT analysis of the Côte d'Ivoire Republic oil and gas complex.

\begin{tabular}{ll}
\hline Strengths & Weaknesses \\
\hline - significant amount of forecast resources; & - capital-intensive structure of the complex; \\
- equipment for hydrocracking (two atmospheric & - lack of geological data and long-term process of \\
distillation units of 75,000 barrels per day and & geological exploration; \\
a hydro-reactor of 18,000 barrels per day); & - difficult development conditions; \\
- major exporter of petroleum products; & - lack of a clear investment attractiveness policy; \\
- state priority; & - lack of a unified state strategy for the development \\
- presence of foreign companies & of the oil and gas complex to increase revenues \\
& from the oil and gas production; \\
& - lack of necessary infrastructure; \\
& - unstable growth in crude oil and natural gas pro- \\
& duction from 2015 to 2018; \\
& - an insufficiently effective and transparent legal \\
& and tax system; \\
& - low technological structure; \\
& - high depreciation of fixed assets \\
\hline Opportunities & Threats \\
\hline - expansion of the oil and gas using (growth in & -high risks of changes in oil and gas prices; \\
internal and external demand); & - development of alternative energy and fuel \\
- introduction of new technologies for the develop- & sources; \\
ment of oil and gas fields. & - negative impact on ecosystems of the coastal zone \\
- liquefied natural gas projects development & of Côte d'Ivoire; \\
& - lack of incentives for subsoil users (economic, \\
& administrative, financial) to implement projects; \\
& - further decline in investment activity \\
\hline &
\end{tabular}


The oil and gas complex of Republic of Côte d'Ivoire has a number of strengths, the potential for development and can become a key factor in the country's economy development for the following reasons:

1. The exploitation of oil and gas fields will increase budget revenues and the level of wellbeing of society.

2. Providing own needs in oil products.

3. Obtaining additional income from the sale of refined products.

4. Stimulating the development of related sectors of the economy.

However, as can be seen from the Table 1, in recent years there has been an increase in negative trends in the development of the oil and gas complex of Côte d'Ivoire Republic, due to various factors, including the lack of policy incentives and the underdevelopment of the regulatory framework.

Policy incentives and the regulatory framework plays a decisive role for the successful development of various industries, including oil and gas. The formation of a favorable investment climate, the expansion of the mineral resource base is impossible without targeted political intervention through the development of a regulatory framework, the formation of a system of incentives and restrictions, the introduction of support mechanisms, international cooperation. All existing instruments of state regulation can be classified as administrative and economic. Administrative is actively used with the aim of directly influencing the object of regulation: legislative acts, standards, prohibitions. With the help of economic instruments, state structures act on objects of regulation in order to ensure their necessary behavior by influencing material interests. Economic methods provide more options for choosing actions, since they are indirect methods that motivate effective investment. Moreover, economic and administrative instruments of state regulation are interconnected. So, any instrument related to economic carries the elements of administration, since it is controlled by one or another state structure.

Figure 3 shows the process of oil and gas complex state regulation in Côte d'Ivoire Republic.

The Government of Côte d'Ivoire Republic as an oil-producing country has adopted a series of laws defining activities in the oil industry, in particular the Petroleum Code, which

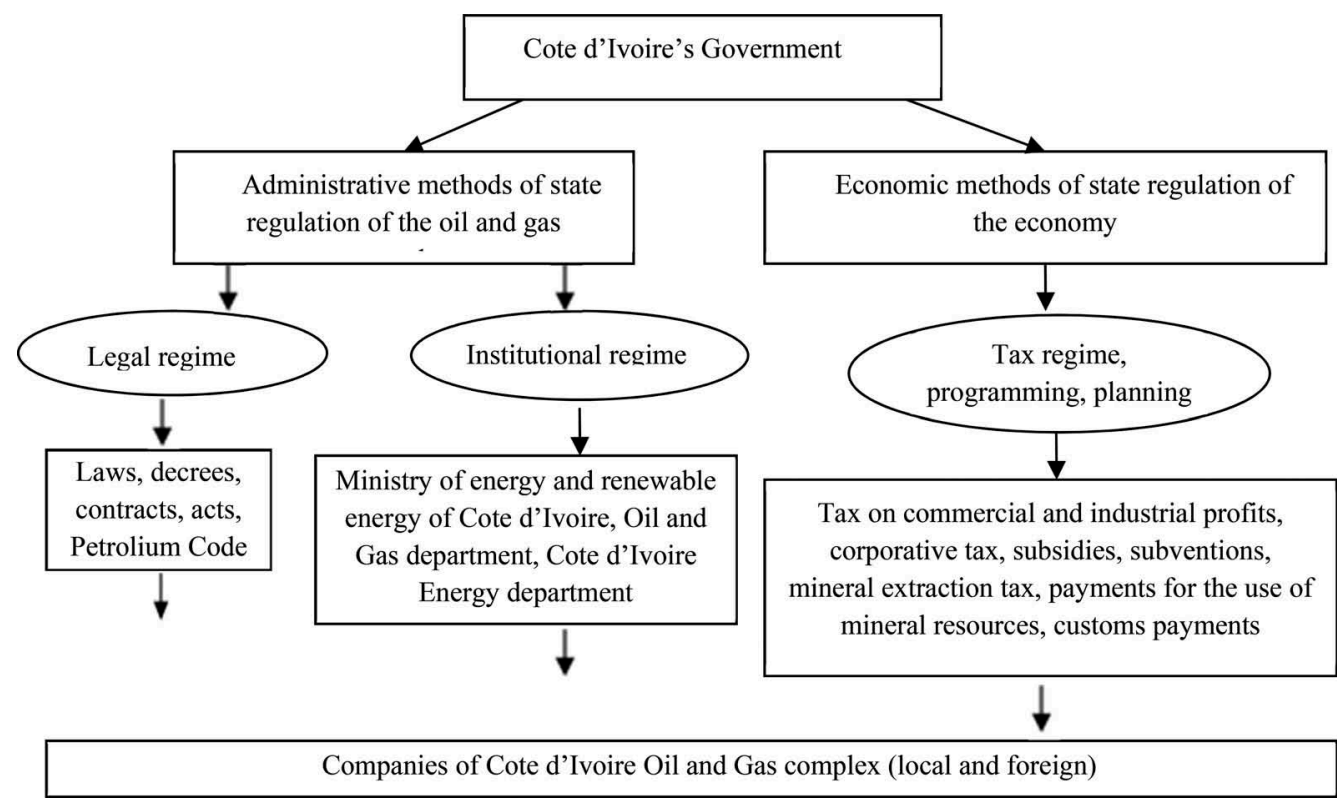

Figure 3. The mechanism of Cote d'Ivoire oil and gas complex state regulation. 
defined Côte d'Ivoire's oil policy. The national oil company Petroci was created, which became an instrument for implementing the national oil policy. The following tasks were set for this company (Amadou \& Makarova):

- research and exploitation of deposits of all types of hydrocarbons;

- Association of industry, transport and trade in hydrocarbons and their products;

- Supervision of all financial transactions related to oil industry facilities.

Côte d'Ivoire Product Sharing Agreement Model

Part I. Norms and procedures governing the right of a contractor to conduct oil transactions, as well as a description of the contract territory.

Part II Description of financial conditions and production features. The contractor provides all the financing and technology that is required to carry out activities under the contract, and assumes the risk associated with costs. Therefore, investor is economically interested in the effective development of the field on the contract area.

Part III. Rules and procedures relating to production sharing (including compensation and remuneration of the contractor) and the rules for the payment of income tax for the contractor

The remaining part of the oil recovered after reimbursement is divided between the contractor and PETROCI on the terms specified in the contract (often $10 \%$ to $15 \%$ of the oil recovered depends on the contract). Contractor income tax is levied after PETROCI withdraws its share of the profits. PETROCI pays the remaining taxes associated with the contract work.

Part IV. Aspects of organization and cooperation. PETROCI represents the Government of Côte d'Ivoire to the contractor, the contractor is responsible to PETROCI for its activities in accordance with the terms of the contract. Ownership of equipment and information. All equipment purchased and delivered in Côte d'Ivoire by the contractor becomes the property of PETROCI. Equipment of service companies and leased equipment are returned. All information obtained during the contract work is the property of PETROCI.

Part V. Legal and non-operational issues. The main obligation is that the contractor should provide $75 \%$ of local participation in the work.

To attract investment in the Cote d'Ivoire oil and gas complex, it is necessary to develop an organizational and economic mechanism providing for regulatory framework development in such areas as tax legislation, investment, provision of mineral resources for use, and lending.

Government policies to support the Cote d'Ivoire oil and gas complex should include the following:

1. Stimulation of monetary relations, involving the creation of an objective environment for the development and successful functioning of local companies

2. Optimization of tax legislation, providing an effective regime for the foreign and local companies

3. Creation of an investment climate conducive to attracting foreign companies to exploration

4. Development of an understandable strategy and programs in the field of oil and gas production, oil refining, transportation of oil and gas resource

5. Improving the mechanism for oil and gas exploitation by reviewing the conditions for concluding production sharing agreements

A more detailed presentation of this mechanism will be considered in future studies.

\section{CONCLUSION}

Republic of Côte d'Ivoire ranks first in the world to produce cocoa beans and one of the leading positions in the export of coffee and palm oil. However, in recent years, the prices of these goods have been unstable, therefore the country's government is forced to diversify the economy, primarily due to the development of the oil and gas sector. 
For a long time, oil and gas production in Côte d'Ivoire grew and the country was considered as one of the promising areas for the search and production of hydrocarbons. However, the civil war in 2011 led to a serious drop in oil and gas production, the restoration of which occurred only in 2015. Today, a number of negative trends are contributing to a decrease in the country's investment attractiveness. The paper identifies the main trends in the development of the oil and gas complex of Côte d'Ivoire, analyze and classify instruments and methods of state regulation.

In the research the authors came to conclusion that such aspects as planning and programming at the state level, clear legislation, adequate country-specific taxation and crediting are critical to investment attractiveness increasing and the Cote d'Ivoire oil and gas complex development.

\section{ACKNOWLEDGEMENT}

The research was carried out with the financial support of the Russian Foundation for Basic Research (RFBR), the project "Evolution of methodology of technological forecasting of development of the interconnected industrial and social and economic systems at hydrocarbon resources development in the Arctic " No. 18-010-00734".

\section{REFERENCES}

Amadou, K. S. \& Makarova, M.G. 2014. Assessment of opportunities for elimination oil contamination of the coastal area of Cote d'Ivoire Vestnik RUDN Ecology and Life Safety series 4: 89-96.

Agyekum, E.B., Ansah M.N.S. \& Afornu K.B. 2020. Nuclear energy for sustainable development: SWOT analysis on Ghana's nuclear agenda Energy Reports 6:107-115 https://doi.org/10.1016/j. egyr.2019.11.163.

Araujo, F.C. \& Leoneti, A.B. 2019. How attractive is Brazil's oil and gas regulatory framework to investors? The Extractive Industries and Society 6(3): 906-914 https://doi.org/10.1016/j.exis.2019.05.009.

Ayanoore I., 2020. The politics of local content implementation in Ghana's oil and gas sector The Extractive Industries and Society Article in press.

BP: Statistical Review of World Energy - 2019 edition. Available at: https://nangs.org/analytics/bp-statis tical-review-of-world-energy.

Côte d'Ivoire - Country Strategy Paper (CSP 2018-2022) combined with 2018 Country Portfolio Performance Review African Development Bank Group https://www.afdb.org/en/countries/west-africa/ cote-divoire.

Cherepovitsyn, A., Moe, A. \& Smirnova, N. 2016. Development of transboundary hydrocarbon fields: Legal and economic aspects Indian Journal of Science and Technology 9(46), doi:10.17485/ijst/2016/ v9i46/107527.

Deberdieva, E.M. 2015. Regulation of the oil and gas sector of the economy: state and corporate aspects Theory and practice of social development 6: 60-62.

Florêncio, P. 2016. The Brazilian 2010 oil regulatory framework and its crowding-out investment effects Energy Policy 98: 378-389 https://doi.org/10.1016/j.enpol.2016.08.038.

Graham, E. \& Ovadia, J.S. 2019. Oil exploration and production in Sub-Saharan Africa, 1990-present Trends and developments The Extractive Industries and Society 6(2): 593-609 https://doi.org/10.1016/j. exis.2019.02.001.

Gorbunova, E.N. 2015. Reforming the tax system of the Russian oil sector Taxes and Financial Law 4: $124-127$.

Gubin, E.P. 2018. State regulation of the market economy and entrepreneurship. Legal problem JURIST-M: 320.

Hansen, M.W. et al. 2016. The economics and politics of local content in African extractives: Lessons from Tanzania, Uganda and Mozambique Forum for Development Studies, Taylor \& Fransis.

Hunter, T. 2014. The role of regulatory frameworks and state regulation in optimising the extraction of petroleum resources A study of Australia and Norway The Extractive Industries and Society 1(1): 48-58 https://doi.org/10.1016/j.exis.2014.02.001.

Kapkanchikov, S.G. 2018. State regulation of the economy KnoRus-M: 528. 
Khatib, H. 2014. Oil and natural gas prospects Middle East and North Africa Energy Policy 64: 71-77 https://doi.org/10.1016/j.enpol.2013.07.091.

Kuadio, A. K. D \& Dukart S. A. 2017. Prospects for the development of the economy of Cote d'Ivoire Materials of the International scientific-practical conference (Novosibirsk) 2 (161)

Lewis,William Arthur, 1955. The theory of economic growth Allen \& Unwin: 455

Lipina, S.A., Bocharova, L.K. \& Belyaevskaya-Plotnik L.A. 2018. Analysis of Government Support Tools for Mining Companies in the Russian Arctic Zone. Zapiski Gornogo Instituta 230: 217-222. https://doi.org/10.25515/PMI.2018.2.217.

Liu, J. et al. 2010. Exploration targets in the Côte d'Ivoire-Ghana transform margin in Equatorial West Africa Petroleum Exploration and Development February 37(1): 43-50 https://doi.org/10.1016/S18763804(10)60013-4.

Mayer, A. 2017. Political identity and paradox in oil and gas policy: A study of regulatory exaggeration in Colorado US Energy Policy 109: 452-459 https://doi.org/10.1016/j.enpol.2017.07.023.

Melyoki, L.L. The governance of the petroleum sector in Tanzania Institutional arrangements and the role of the National Oil Company The Extractive Industries and Society 4(1): 180-190 https://doi.org/ 10.1016/j.exis.2016.12.005.

Mihalchenkova, N.A. \& Smetanina, T.M. 2004. State regulation of the economy Syktyvkar: KRAG$\mathrm{SiU}: 35$.

Modelevsky, M.S. \& Modelevsky, M.M. 2016. Assessment of the discovered and undiscovered oil and gas of Africa Russian Geology and Geophysics 57(9): 1342-1348 https://doi.org/10.1016/j.rgg.2016.08.019.

Mukesh, S.S.S. 2019. Impact of regulatory framework on bidding behavior of firms policy implications for the oil \& gas sector Energy Policy 131: 33-42 https://doi.org/10.1016/j.enpol.2019.01.075.

Ovadia, J.S. 2016. Local content policies and petro-development in Sub-Saharan Africa A comparative analysis Resources Policy 49: 20-30 https://doi.org/10.1016/j.resourpol.2016.04.003.

Orechin, V.P. 1999. State regulation of the national economy V. P. Oreshin. - Moscow: Moscow state University. M. V. Lomonosova 1999: 12.

Paz, M.J. \& Ramírez-Cendrero, J.M. 2013. How important are national companies for oil and gas sector performance? Lessons from the Bolivia and Brazil case studies Energy Policy 61: 707-716 https://doi. org/10.1016/j.enpol.2013.05.126.

Ramírez-Cendrero, J.M. \& Paz, J.P. 2017. Oil fiscal regimes and national oil companies: A comparison between Pemex and Petrobras Energy Policy 101: 473-483 https://doi.org/10.1016/j.enpol.2016.11.009.

Rostow, W. W. 1971. Politics and the Stages of Economic Growth Cambridge.

Romasheva,N. \& Ilinova A. 2019. CCS Projects: How Regulatory Framework Influences Their Deployment Resources 8(4), 181 https://doi.org/10.3390/resources8040181.

Smirnova, N.V. \& Rudenko, G.V. 2016. Priorities for improving taxation in oil industry in Russia. Indian Journal of Science and Technology 9(19). doi:10.17485/ijst/2016/v9i19/93907.

Trofimov, S.E. 2018. On state regulation of the oil and gas complex Voprosy Ekonomiki 1: 151-160 https://doi.org/10.32609/0042-8736-2018-1-151-160. 